\title{
"Det känns lustigt. Det känns gåtfullt"
}

\author{
Kärlekens problematik i Tito Collianders författarskap i en rysk litterär och \\ filosofisk kontext
}

Litteraturvetaren Göran O:son Waltå karakteriserar Tito Collianders romangestalter som "de utslitna vrakspillrorna och de trasiga - flyktingar i andlig och bokstavlig mening", något som han tillskriver Fjodor Dostojevskijs tradition. Han drar raka paralleller mellan Colliander och Dostojevskij genom att beteckna en av Collianders protagonister - Boris i romanen Korstaget - som "den vackra, allvarliga, helgonlika Raskolnikov-skepnaden som förföljer Tomas livet ut". ${ }^{1}$ Parallellerna mellan Colliander (I904-I989) och Dostojevskij (I82I-I88I) utvecklas av Torsten Kälvemark som beskriver litteraturvetarnas och kritikernas sätt att betrakta Colliander som "Finlands Dostojevskij” som en något sliten kliché. Trots det kritiska tonfall som tydligt hörs i ordet kliché erkänner Kälvemark det uppenbara släktskapet mellan de två författarskapen. ${ }^{2}$

I. Göran O:son Waltå,"Krisen och litteraturen på trettiotalet”, Finlands svenska litteraturbistoria II. Andra delen: Igoo-talet, Clas Zilliacus (utg.), Helsingfors: Svenska litteratursällskapet i Finland \& Stockholm: Atlantis 2000, s. I37. Med denna "vackra, allvarliga, helgonlika skepnad" avser O:son Waltå Boris, Korstågets martyrgestalt som blir ihjälslagen av en rasande folkmassa i det revolutionära Petrograd. I romanen är Boris en bärare av den kristna kärlekens idé; han älskar alla och ser något gott och ljust i varje människa. I detta avseende påminner Boris mest om Dostojevskijs Lev Mysjkin, protagonisten i Idioten (I869). O:son Waltås jämförelse mellan Boris och Rodion Raskolnikov bygger mest på de utseendemässiga likheterna: samma mörka glödande ögon, regelbundna ansiktsdrag och svart sliten klädsel.

2. Torsten Kälvemark, "Den levande vaxljuslågans språk - anteckningar om Tito Collianders författarskap", Torsten Kälvemark, Låset av ull. Utsikter över andliga landskap, Skellefteå: Norma bokförlag 200I, s. I8I. 
Även om Colliander har betecknats som Finlands Dostojevskij, har hans författarskap i tidigare forskning inte analyserats i en rysk filosofisk kontext. ${ }^{3}$ Mitt övergripande syfte i den här artikeln är att utforska de etiska beröringspunkter och skillnader som finns mellan Dostojevskijs syn på kärleken och Collianders framställning av kärlekens problematik i romanerna Korstaget (1937), Grottan (1942) och Bliv till (1945). Detta gör jag genom att begrunda begreppet kärlek i Dostojevskijs och Collianders respektive författarskap. Hur förhåller sig författarna till kärleken? Vilka uttryck tar sig kärleken hos Dostojevskij och Colliander? Hur förhåller sig den erotiska kärleken, det vill säga kärleken mellan två människor som känner fysisk dragning till varandra, till kärleken till Kristus som är rent andlig

3. I tidigare forskning har Collianders väg till den ortodoxa kyrkan, med utgångspunkt i hans memoarsvit, beskrivits av Astrid Andersson Wretmark i boken Tito Colliander och den ryska heligheten, Stockholm: Artos 2008. Thomas Warburton gör flera intressanta iakttagelser om Collianders författarskap i Åttio år finlandssvensk litteratur, Stockholm: Alba 1984. Merete Mazzarella skriver om Collianders författarskap och livserfarenhet i boken Att skriva sin värld. Den finlandssvenska memoartraditionen, Helsingfors: Söderström 1993, och i artikeln "Att använda sin erfarenhet - Tito Collianders Korståget i självbiografisk belysning", Pia Forssell \& John Strömberg (red.), Historiska och litteraturbistoriska studier 78, Helsingfors: Svenska litteratursällskapet i Finland 2003, s. I49-158. Se även Mazzarellas översikt över finlandssvensk memoarlitteratur, "Memoarer och självbiografier", i Finlands svenska litteraturbistoria II, s. 22I-222. Collianders självframställning står i fokus för Helena Bodins undersökning "Den bysantinska bron. Tito Collianders memoarer", som ingår i hennes bok Bruken av Bysans. Studier i svenskspråkig litteratur och kultur 1948-7I, Skellefteå: Norma 20II, s. 395-42I. Bodin har också studerat flerspråkighetens problematik i Collianders memoarsvit i artikeln "So let me remain a stranger': Multilingualism and biscriptualism in the works of Finland-Swedish writer Tito Colliander", Heidi Grönstrand, Markus Huss \& Ralf Kauranen (eds.), The Aesthetics and Politics of Linguistic Borders: Multilingualism in Northern European Literature, New York: Routledge 2020, s. 242-262. Collianders språkliga och geografiska gränsöverskridande analyseras i Bodins artikel "Gränslandets österländskhet' - om svenskspråkiga reseskildringar från Valamo”, Clas Zilliacus, Heidi Grönstrand \& Ulrika Gustafsson (red.), Gränser i nordisk litteratur: Borders in Nordic Literature, IASS XXVI 2006, Vol. II, Åbo: Åbo Akademis förlag 2008, s. 67o. Olov Hartman, svensk präst, författare och psalmdiktare, ägnar ett kapitel, "Bedjaren och betraktaren", åt Collianders religiösa världsåskådning i sin bok Ikon och roman, Stockholm: Skeab i980. Torsten Pettersson undersöker psyket och yttervärlden i Collianders romaner i artikeln "Att han ingenting förstod'. Psyket och yttervärlden i Tito Collianders romaner", som ingår i Ben Hellman \& Clas Zilliacus (red.), Tio finlandssvenska författare, Helsingfors: Svenska litteratursällskapet i Finland I986, s. 99-I2I. 
och befriad från det kroppsliga? Vari ligger orsaken till den erotiska kärlekens tragik? En analys av kärlekens problematik i Collianders romaner öppnar upp för en djupare förståelse av Collianders förhållningssätt till den ryska litterära och filosofiska traditionen och kastar ljus över de motsägelser som ligger till grund för hans författarskap och religiösa världsåskådning.

De frågor jag ställer kommer att besvaras med utgångspunkt i Collianders respektive Dostojevskijs författarskap och de ryska filosoferna Vladimir Solovjovs (I853-I900) och Nikolaj Berdjajevs (I874I948) tolkningar av kärlekens problematik. I artikeln närmar jag mig Collianders texter genom Dostojevskij och de ryska filosoferna. Kärlekens problematik i Dostojevskijs författarskap betraktar jag i ljuset av Berdjajevs kärleksfilosofi och hans tolkningar av Dostojevskijs texter. Hans reflexioner om Eros och den erotiska kärleken i Dostojevskijs författarskap återger det väsentliga i dennes framställning av kärleken, nämligen kärlekens dialektik som omfattar kärlekens motsatta poler. Även Solovjovs kärleksfilosofi blir en nyckel till förståelse av Dostojevskijs författarskap.

\section{Colliander - Finlands Dostojevikij?}

I sin essä "Den levande vaxljuslågans språk - anteckningar om Tito Collianders författarskap" utvecklar Torsten Kälvemark den konventionella synen på Colliander som en finländsk Dostojevskij genom att lyfta fram den gemensamma grunden för de två författarnas påstådda släktskap, nämligen att de delar en människosyn med rötter i den ortodoxt kristna traditionen: "Men denna människosyn handlar inte bara om lidande, förbarmande och försoning, den handlar också om tröst, glädje och uppståndelse." ${ }^{4}$ Det är inte lidande utan just tröst, glädje och uppståndelse som Dostojevskij och Colliander söker i den ortodoxa tron. Iakttagelsen är betydelsefull för förståelsen av de filosofiska och etiska beröringspunkterna mellan Dostojevskij och Colliander som står i fokus i den här artikeln.

Collianders andliga erfarenheter tar sig uttryck i en föreställd geo-

4. Kälvemark, ”Den levande vaxljuslågans språk”, s. ı8r. Kälvemarks essä är ett viktigt inlägg i tolkningen av Collianders skönlitterära skildringar av den ortodoxa tron. 
grafi, där de vistelseorter i Ryssland och Finland som han passerar på livets väg antar imaginära former, styrda av spänningen mellan flykt och återkomst, hemlängtan och främlingskap. Colliander var född i S:t Petersburg 1904 och växte upp i en kosmopolitisk miljö. Hans föräldrar hade finlandssvenskt och skotskt ursprung och tillhörde den militära adelskretsen. Fadern, Sigfrid Colliander, var född på Sveaborg och blev senare i livet finländsk officer i rysk tjänst. Före Titos födelse tjänstgjorde han vid första transkaspiska skarpskyttebataljonen i Ashabad, vid gränsen mellan Ryssland och Persien. År I9o6 anhöll Sigfrid om avsked från sin militärtjänst och var därefter verksam som affärsman fram till I9ı6 och det första världskriget, då han återupptog sin militära karriär. Modern, Dagmar Ilmatar Constance von Schoultz, var född i Ryssland där hennes far deltog i järnvägsnätets utbyggnad. Hennes barndomshem Runolinna vid Saima kanal nära Viborg brann I873. ${ }^{5}$

Den ortodoxa tro som ligger till grund för Collianders livsåskådning och hans djupa koppling till den ryska litteraturens tematik är en naturlig följd av hans uppväxt som präglades av kyrkobesök och slaviska kyrkosånger. I Kälvemarks essä om Colliander förekommer en intressant tanke angående Collianders relation till den ortodoxa kyrkan, som inte var resultatet av någon dramatisk religiös kris utan en "mognad återupplevelse av några barndomsår i hungerns och revolutionens Petrograd". ${ }^{6}$ Collianders förbindelser med den ryska kulturen realiseras i två riktningar: den ena går mot den ryska ortodoxa kyrkan, den andra mot den ryska litteraturen.

Collianders insatser för den svenskspråkiga ortodoxa kyrkan i Finland och Finska ortodoxa församlingen i Sverige är betydelsefulla. Som teologie hedersdoktor med prästexamen från Ortodoxa prästseminariet i Finland I965 var Colliander lärare i Helsingfors för alla svenskspråkiga elever som hörde till den ortodoxa kyrkan i Finland. Han bidrog till den svenskspråkiga ortodoxa kyrkans framväxt i Norden genom sina teologiska studier, föredrag och handböcker om den ortodoxa tron, till exempel Grekisk-ortodox tro och livssyn (I95I), Asketernas väg (1952), Nu och alltid. Studier i ortodox kristendom (I958)

5. Andersson Wretmark, Tito Colliander och den ryska heligheten, s. II.

6. Kälvemark, "Den levande vaxljuslågans språk", s. I85. 
och Fyra föredrag rörande ortodoxa kyrkans verksambet på svenskt språkområde (1968). Colliander var en brobyggare mellan nordisk kultur och den rysk-ortodoxa tron också genom sina översättningar av ortodoxa hymner och liturgiska texter, bland annat Vår helige faders Johannes Chrysostomos gudomliga liturgi (1958).

I en essä om Dostojevskij formulerar Colliander de postulat som ligger till grund för Dostojevskijs filosofi och som även blir utgångspunkter för hans eget författarskap. Framför allt betonar han den stora betydelse som Kristusgestalten har i Dostojevskijs världsåskådning. Som belägg för detta citerar Colliander några utdrag ur Onda andar (I872), där Kristus uppfattas som en vanlig människa med enorma andliga krafter som försonar människorna med varandra och frälser dem från förtvivlan:

För honom [Dostojevskij] är Kristus kyrkans fullkomliga Gud och fullkomliga människa i en person, den livskälla som uppfyller och genomlyser kosmos, som ordnar människovarats kaos, tränger in i de djupaste avgrunderna och renar och befriar de mest nedsmutsade tillvaroformer. ${ }^{7}$

Colliander framhäver Kristusbildens betydelse för Dostojevskij genom att avsluta sin essä med ett citat som kan anses uttrycka det väsentliga i dennes filosofi, som bygger på tanken om kärlekens frälsande roll i människans liv: ”Åter och åter [...] fylls jag av brinnande kärlek vid tanken på Honom - på Herren Jesus Kristus."

En stor del av essän ägnar Colliander åt lidandets problematik i Dostojevskijs livssyn. Han lyfter fram en tanke som skulle bli en filosofisk utgångspunkt för hans eget skrivande: lidandet som en vinning. Både Dostojevskijs liv och författarskap visar enligt Colliander

7. Tito Colliander, Nu och alltid. Studier i ortodox kristendom, Helsingfors: Söderströms I958, s. I33.

8. Ibid., s. I50. Colliander anger ingen källa för yttrandet, men det citerade avsnittet står i samklang med ett välkänt citat av Dostojevskij i ett brev som han skrev I854 i Omsk till Natalia D. Fonvizina: "Om någon hade bevisat mig, att Kristus står utanför sanningen, så skulle jag ändå föredra att stanna med Kristus och icke gå med sanningen." Fjodor Dostojevskij, "Till fru N.D. Fonvizina”, Brev i urval och översättning av Alfred Jensen, Stockholm: P.B. Norstedt \& Söners förlag I920, s. 77 . 
att lidandet är en ovärderlig erfarenhet för människan genom att den leder till självrannsakan och därmed till uppståndelse. Han påpekar att begreppet lidande hos Dostojevskij är oupplösligt sammankopplat med begreppet medlidande som syftar på "en hjärtats djupa gemenskap med allt som våndas och lider". ${ }^{9}$ Lidandet och medlidandet bottnar i kärleken som är den enda vägen till befrielse från det imaginära källarhålet, där vi alla är högmodets, självhävdelsens och gudsförnekelsens fångar. Sammantaget kan man säga att Collianders syn på Dostojevskijs författarskap bygger på följande idéer och begrepp: Kristusbildens absoluta värde i människans liv, lidandets och medlidandets läkande kraft och kärleken som den enda vägen till inre frihet och äkta lycka.

Dostojevsijus författarskap i ljuset av Berdjajevs KÄRLEKSFILOSOFI

Dostojevskij visar sig vara en andlig förebild som utövar dragningskraft på Nikolaj Berdjajev. I ett företal till sin omfattande essä Om Dostojerskij (1923) betonar Berdjajev den avgörande roll som Dostojevskij har spelat i hans andliga liv. ${ }^{10}$ Då Berdjajev reflekterar över friheten finner han "sin rätta hemort" hos Dostojevskij. Även Berdjajevs syn på Kristus utformas och utvecklas under Dostojevskijs inflytande, bland annat i hans läsning av "Legenden om Storinkvisitorn" som Ivan Karamazov, Bröderna Karamazovs protagonist, berättar för sin bror Aljosja Karamazov.

I sin tolkning av Dostojevskij är Berdjajev inte i första hand litteraturvetare utan filosof, som genom reflektioner kring Dostojevskijs etiska hållning och romangestalternas ord och handlingar kommer åt den ryska tillvarons betydelsefulla matriser. I viss mån är Berdjajev en del av dessa matriser; han analyserar Dostojevskijs värld samtidigt som han identifierar sig med denna. Genom att läsa Dostojevskij besvarar Berdjajev de "förbannade" eviga ryska frågor som han ställer sig själv: Var ligger frihetens gräns? Hur förhåller sig

9. Colliander, $\mathrm{Nu}$ och alltid, s. I45.

Io. Nikolaj Berdjajev, Om Dostojerskij, översättning till svenska: Gösta Andersson, Skellefteå: Artos Bokförlag I992, s. 6. 
människans tro till tvivel och frihet? Vad är den sanna kärleken? Vad är dödens gåta? I sin världsåskådning rör Berdjajev vid Dostojevskijs etiska kärna och blottar de väsentliga motsägelser som karakteriserar Dostojevskijs sammansatta dialektik.

Genom att resonera om kärlekens problematik hos Dostojevskij formulerar Berdjajev sin egen kärleksfilosofi i vilken frågan om friheten är central. De flesta av Berdjajevs iakttagelser om kärlekens uttryck hos Dostojevskij i essän Om Dostojerskij sammanfaller med dem i hans essä "Reflexioner om Eros", som i sin tur ingår i hans filosofiska självbiografi Vägar till självkännedom (I940, publicerad postumt I949).

Trots att Berdjajev använder begrepp som "den erotiska kärleken", "Eros", "den sexuella driften", "sensualitet", "liderlighet" och "medlidande" på ett fritt och egenmäktigt sätt. Han definierar inte dessa begrep, utan väver in dem i sin diskussion och låter läsaren göra egna tolkningar och dra egna slutsatser. Berdjajev skiljer mellan den erotiska kärleken och den sexuella driften eller könsdriften. Könslivet är opersonligt och ansiktslöst; den blinda sexuella driften förbiser och till och med tillintetgör den andra människans personlighet. Däremot är den erotiska kärleken personlig och individuell; den riktar sig mot ett ansikte som är unikt och oersättligt. ${ }^{11}$

Den erotiska kärleken har sina rötter i könet, utan vilket den inte kan existera, men som den samtidigt övervinner. Enligt Berdjajevs iakttagelser kan den starka erotiska kärleken försvaga könsdriften i stället för att göra den starkare. Könet är en del av släktets liv, medan den erotiska kärleken är en del av individens liv. Den erotiska kärleken är mycket komplicerad och motsägelsefull och skapar därför talrika konflikter i människans tillvaro. Trots att begreppet"den erotiska kärleken" hänger ihop med begreppet Eros likställs de två inte i Berdjajevs reflexioner. Berdjajev uppfattar Eros - i linje med den klassiska filosofin som härleder sitt ursprung från antikens Grekland - som en gudomlig kraft som kommer från en annan värld och tillhör det transcendenta. Denna kraft tar människan i besittning och får henne att uthärda den erotiska kärlekens plåga. ${ }^{12}$

II. Nikolaj Berdjajev,"Reflexioner om Eros", Nikolaj Berdjajev, Vägar till självkännedom, översättning till svenska: Stefan Borg, Skellefteå: Artos bokförlag I994, s. 84 .

I2. En förandligad Eros, det bildliga uttrycket för den i människosjälen inneboende längtan efter det goda och det sköna, förekommer hos Sokrates och Platon, vars 
Det väsentliga i Dostojevskijs skildring av den erotiska kärleken är enligt Berdjajev att kärleken i sig är demonisk och tragisk. Som exempel på detta anges bland annat Andrej Versilovs exalterade kärlek till Katarina Nikolajevna som "skapar en atmosfär, som håller alla de andra personerna i ett tillstånd av en olidlig spänning”, ${ }^{13}$ Dmitrij Karamazovs förtärande passion för Grusjenka och Parfjon Rogozjins besatthet av Nastasya Filippovna. Anledningen till kärlekens tragik ligger inte i yttre omständigheter, som till exempel i att kärleken är obesvarad eller i att en av de älskandes civilstånd hindrar det förälskade paret från att förenas. Tragiken ligger i de manliga protagonisternas inre kluvenhet som inte kan övervinnas med hjälp av kärleken - utan tvärtom blir ännu djupare av kärlek. I Berdjajevs tolkning av Dostojevskijs kärleksfilosofi tilldelas just mannen den tragiska huvudrollen medan kvinnan blir en katalysator som utlöser mannens inre plåga: "Den maskulina naturen är söndrad. Den kvinnliga är ännu dunkel, men den uppenbarar en avgrund, där mannen kan störta ned." ${ }^{14}$ Kärleken hos Dostojevskij blir splittrad och tragisk i alla dess former och yttringar.

I sin tolkning av kärlekens problematik hos Dostojevskij skiljer Berdjajev mellan olika former av kärlekslidelse. Dessa är sensualiteten och medlidandet som utgör kärlekens motsatta poler. Sensualiteten är en översättning av Berdjajevs "sladostrastie" som också kan översättas som "vällust". När Berdjajev skriver att de flesta av Dostojevskijs manliga karaktärer lider av en överdriven sensualitet, menar han att de lider av ett överflöd av passion eller sexuell dragning som är riktad mot en enda kvinna som upptar hela deras väsen. En sådan passion uttrycker till exempel Andrej Versilov i Ynglingen (1875), denna profet för kvinnor, vars hemliga kärlek skapar en stämning av "förvirrande lidelser", Parfjon Rogozjin i Idioten (I869) och Dmitrij Karamazov i Bröderna Karamazov (I880), som alla blir vällustens slavar på ett sätt som leder dem själva och de kvinnor de älskar till ett tragiskt

dialog Symposion ägnas åt reflexioner kring Eros väsen. Samma tanke framträder i den allegoriska myten om Eros och Psyche, som gestaltas i Metamorfoser av den romerska författaren Lucius Apuleius.

I3. Berdjajev, Om Dostojerskij, s. 95 .

I4. Ibid. 
slut; Rogozjin tar Nastasya Filippovna i besittning genom att mörda henne, medan Dmitrij Karamazov blir oskyldigt dömd till straffarbete i Sibirien för ett fadermord som han inte har begått.

Sensualitetens eller vällustens motsatta pol är medlidandet som på originalspråket ryska låter som "so-stradanie" (ryskans stradanie betyder lidande). Medlidandet hos Dostojevskij innebär människans (ofta mannens) lidande och är förorsakat av en konkret person. Berdjajev uppfattar medlidandet som en av kärlekens former, som i likhet med vällusten har en extatisk karaktär. En bärare av medlidandet som en form av kärlek är Lev Mysjkin, protagonisten i romanen Idioten:

Hans lidelse saknar kött och blod. Med så mycket mera styrka utvecklas hos honom kärlekens motsatta sida, medkänsla. Han älskar Nastasya Filippovna med en oändlig medömkan och ett oändligt medlidande. Denna medömkan innesluter i sig en destruktionens princip, ty den uppenbarar Mysjkins självrådighet och överskrider gränserna för vad som är tillåtet för människan. ${ }^{15}$

Mysjkins medlidande är lika överdrivet och gränslöst som Parfjon Rogozjins vällust. Det intressanta är att samma kvinna hos olika män väcker motsatta känslor, som till exempel Nastasia Filippovna som framkallar ett oändligt medlidande hos Mysjkin och en stormande vällust hos Rogozjin. Berdjajev betonar att varken medlidande eller vällust leder till en lycklig och slutgiltig förening med en kvinna, utan allid till ångestens och besatthetens avgrund.

Hos Dostojevskij står sensualiteten i motsatsförhållande till liderligheten. Liderligheten är en fri översättning av Berdjajevs begrepp razvrat som också kan översättas som sedeslöshet eller sexuell utsvävning. Skillnaden mellan liderligheten och sensualiteten är en skillnad mellan könet och den erotiska kärleken. Liderligheten, liksom den blinda könsdriften, sliter sönder och förgör personligheten medan sensualiteten söker efter den. Sensualiteten handlar om ett medvetet val medan liderligheten medför att man saknar förmågan att välja fritt: "Sensualiteten är liksom en ström av eld, men när sensualiteten

I5. Ibid., s. 96 . 
blir liderligheten, slocknar den flammande strömmen och förvandlas till iskyla." 16

I Berdjajevs tolkning står sensualiteten, som karakteriseras av en viss glöd och ett mänskligt hjärta, i ett motsatsförhållande till liderligheten som är icke-mänsklig. Arkadij Svidrigajlov i Brott och straff (I866), aristokraten Nikolaj Stavrogin i Onda andar och bröderna Karamazovs far, Fjodor Karamazov, tillhör liderlighetens kungarike som Berdjajev betecknar som "icke-varats illusoriska värld". ${ }^{17}$ De här karaktärerna skiljer inte längre mellan det goda och det onda, mellan den oskuldsfulla Madonnan och det fallna Sodom, vilket innebär en andlig och till och med fysisk död.

Kärleken är alltid selektiv och personlig och därför är liderligheten kärlekens upplösning. Trots kärlekens uppenbara tragik besitter den ändå en livsbejakande kraft. Enligt Berdjajev är kärlekens positiva och ljusa inverkan på människans tillvaro i Dostojevskijs författarvärld möjlig endast genom närvaron av Guds ansikte och genom föreningen i Gud med den älskade. Han framhäver att den sanna kärlekens grund hos Dostojevskij alltid är den kristna kärleken. Med "den sanna kärleken" menar Berdjajev kärleken som placerar själen i odödlighetens sammanhang, som inte förnekar det eviga livet utan ser Guds avbild i varje människa: "Den sanna kärleken är knuten till personligheten, som äger själens odödlighet. Detta gäller för den sexuella kärleken liksom för varje annan form av den mänskliga kärleken." ${ }^{18}$

Utan kärleken till Gud är kärleken till en människa omöjlig, vare sig det handlar om den erotiska kärleken mellan man och kvinna eller moderskärleken. I kärleken som utesluter Gud förnekar människan sin andliga natur, sitt ursprung, sin frihet och sin odödlighet. Ett exempel på en kärlek som är förankrad i den kristna kärleken till Gud representerar Sonja Marmeladova i Brott och straff, som har en förmåga att älska uppoffrande och osjälviskt. Även den unge Aljosja Karamazov har potential att uttrycka sann kärlek genom att Gud ständigt är närvarande i hans liv. Trots att Aljosja medvetet väljer klosterlivet och därför måste avstå från den fysiska kärleken, är han

I6. Ibid., s. Ioo.

I7. Ibid., s. Ioo.

I8. Ibid., s. I05. 
bärare av kärlekens levande kraft. Den utövar han på sina bröder, sin förlorade far och alla de människor som han träffar, i sina försök att lyssna, trösta och försona dem med varandra.

\section{Kärlekens Mening i Vladimir Solovjovs filosofi}

Berdjajevs tolkning av kärlekens problematik hos Dostojevskij står i samklang med Vladimir Solovjovs kärleksfilosofi som han formulerade i sin monografi Kärlekens mening (I892-I894). ${ }^{19}$ I "Reflexioner om Eros" skriver Berdjajev att Vladimir Solovjovs verk sannolikt är "det bästa som har skrivits om kärleken" ${ }^{20}$

I fråga om Solovjov och Dostojevskij kan man tala om ett ömsesidigt andligt inflytande. Filosofen och författaren gjorde en gemensam pilgrimsfärd till Optina Pustynj I878, efter att Dostojevskijs treårige son Aleksej hade dött. ${ }^{21}$ Det som förenar deras tänkande är att båda kritiserade den katolska kyrkans dogmatism och auktoritära karaktär. Rowan Williams gör antagandet att genljud från Solovjovs idé om den fria teokratin hörs tydligt i Bröderna Karamazovs andra del, nämligen i Ivan Karamazovs samtal med Aljosja:

Solovjov skrev själv att han och författaren hade diskuterat dessa frågor under deras gemensamma resa till Optina. Det är möjligt, och till och med troligt, att dessa samtal, som följde efter föreläsningen (som Dostojevskij åhört), delvis påverkade hur Ivans diskurs i romanen formades. ${ }^{22}$

I Bröderna Karamazov hörs även Solovjovs reflektion om den kosmiska andligheten, vilket kan tolkas som ett resultat av det etiska utbytet

I9. Vladimir Solovyov, The Meaning of Love, Translation by Thomas R. Beyer Jr, Hudson, N.Y.: Lindisfarne Books I985.

2o. Berdjajev, "Reflexioner om Eros", s. 89.

2I. Rowan Williams, Dostoevsky. Language, Faith and Fiction, London, New Delhi, New York \& Sydney: Bloomsbury 2008, s. 203.

22. Ibid., s. 209-210. "Solovyov himself wrote that he and the novelist had discussed these matters during their trip to Optina. It is possible, even likely, that these conversations, following on the lecture (which Dostoevsky had attended), bore fruit in some of the shaping of Ivan's discourse in the novel." Översättning till svenska: O.E. 
mellan den unge filosofen och Dostojevskij. Solovjov utgår från tanken att den erotiska kärleken inte har någon betydelse i praktiskt avseende; den starkaste erotiska kärleken har enligt honom ingenting med förökning att göra. Om man ser på världslitteraturens klassiker kan man konstatera att den erotiska kärleken inte är fruktbar och inte lämnar några avkomlingar efter sig. Som ett exempel kan nämnas Johann Wolfgang von Goethes unge Werthers stora passion för Lotte, som är förlovad med den tråkige Albert. Men även den besvarade kärleken leder ofta antingen till ett tragiskt slut eller till ett fridfullt liv utan barn, som i Nikolaj Gogols Starosvetsky markägare (1835) där det barnlösa paret Afanasij Petrovitj och Pultjeria Ivanovna ägnar sitt liv åt ömsesidigt omhändertagande.

Kärlekens mening ligger enligt Solovjov inte i mänsklighetens fortplantning; den är inte ett verktyg för människornas överlevnad utan har sin egen betydelse som kan formuleras som det individuella livets apoteos: "Allmänt talat är den mänskliga kärlekens innebörd ett rättfärdigande av och en frälsning av individualiteten genom uppoffring av egoismen." ${ }^{23}$ I den erotiska kärleken framstår det älskade föremålet i ett alldeles speciellt ljus; den som älskar ser något som andra inte ser, vilket enligt Solovjov inte innebär en villfarelse eller en sinnesförvirring hos den älskande människan. Varje människa är Guds avbild och ursprungligen var människan tänkt som en bärare av den gudomliga idén. Den erotiska kärleken är ett slags katalysator som frigör den andliga och fysiska återuppbyggnaden av Guds avbild i den konkreta människan och i hela mänskligheten.

I sitt förord till en engelskspråkig utgåva av Solovjovs verk Kärlekens mening definierar den brittiske filosofen, poeten och kritikern Owen Barfield kärleken som en mötesplats mellan människotillvarons två nivåer - den horisontala nivån som gäller relationer människor emellan (nivån människa-människa) och den vertikala nivån som gäller människans förhållande till det gudomliga (nivån människa-Gud):

23. Solovyov, The Meaning of Love, s. 42." The meaning of human love, speaking generally, is the justification and salvation of individuality through the sacrifice of egoism." Översättning till svenska: O.E. 
Kärleken för Solovjov är ett kors med både horisontala och vertikala koordinater. Den horisontala nivån, relationen mellan två människor, blir möjlig genom den andra, vertikala nivån, som omfattar allt. ${ }^{24}$

På den horisontala nivån utvecklas relationer mellan människor - inte bara det älskande parets relation, utan de älskandes relationer med omgivningen och hela mänskligheten. På den vertikala nivån upplever den kärleksfulla och älskande människan skapelsens gudomliga väsen. Den sanna kärleken blir ett slags andligt band som låter människan uppleva samhörighet inte bara med den älskade utan med universums gudomliga själ. Meningen med kärleken blir alltså en frigörelse av det andliga bandet som förbinder en människa till en annan människa, till mänskligheten och till Gud.

Solovjov jämför kärlekens mening med språkets mening. Ordens sanna betydelse ligger inte i själva talet utan i det budskap som orden bär på. Meningen med orden är tankens uppenbarelse; på samma sätt som orden är ett medel att framföra ett budskap, ligger kärlekens mening inte bara i själva den spontana känslan utan i den djupa mening som denna omfattar. Kärlekens optik vänder sig mot den andra människans odödliga själ och ser dennas absoluta fullkomliga värde som Guds avbild i den materiella världen. ${ }^{25}$

I likhet med Berdjajev, som framhäver den sanna kärlekens absoluta frihet, framhåller Solovjov tanken att kärleken är en andlig kraft som är fri från sociala lagar och fysiologiska eller djuriska instinkter. Genom att analysera sådana uttryck för sexualitet som sågs som avvikande och stod i fokus för sekelskiftets psykoanalytiska behandlingar framhåller Solovjov att den mest allmänna och dominerande avvikelsen är ett förnekande av det andliga och det mystiska i människan - till förmån för den sociala tryggheten eller den rent sexuella driften. Det äktenskap, vars enda mål är att garantera människans trygghet och sociala status, eller att ge tillgång till sexuellt umgänge uteslutande för

24. Owen Barfield, "Introduction", Vladimir Solovyov, The Meaning of Love, Hudson, N.Y.: Lindisfarne Books I985, s. Ir."Love, for Solovyov, is a cross, with both horizontal and vertical co-ordinates. Its horizontal, human, one-one relation is made possible by its other, vertical, all-in-one coordinate." Översättning till svenska: O.E.

25. Solovyov, The Meaning of Love, s. 57 . 
förökningens skull, kan ses som en avvikelse:"Varken i den heliga eller i den allmänna historien är den sexuella kärleken ett verktyg eller ett instrument med ett historiskt syfte; den tjänar inte människoarten." ${ }^{26}$

Solovjovs syn på äktenskapet som en institution som inte har något med den erotiska kärleken att göra står i samklang med Berdjajevs tanke om den legala kärleken som en död kärlek: "Lagenheten finns bara för normaliteten, medan kärleken överskrider normaliteten." ${ }^{27}$ Det finns även uppenbara beröringspunkter mellan Solovjovs tanke om den fysiologiska sexuella driften - som ett praktiskt verktyg för förökningen som utesluter kärlekens andliga grund - och Berdjajevs reflexion om den erotiska kärlekens omöjlighet utanför kärleken till Gud: "Det är den gudomliga formen och likheten man älskar i sin nästa." 28

De flesta huvudteser som ligger till grund för Solovjovs kärleksfilosofi och Berdjajevs reflexioner om Eros och den erotiska kärleken i Dostojevskijs författarskap står i samklang med Tito Collianders syn på kärlek och sex. Collianders synsätt i denna fråga sammanfattas $i$ Olov Hartmans artikel "Kärlek och sex", som är en del av en längre essä om Colliander, i vilken han betraktas som både bedjaren (den ortodoxa troende som framför den ortodoxa kyrkans budskap) och betraktaren (den iakttagande författaren som tvivlar och ifrågasätter kyrkans föreskrifter och postulat). Utan att gå in på en djup analys av hur kärleken framställs i Collianders skönlitterära verk anger Hartman några betydelsefulla citat från Collianders memoarsvit som belyser hans syn på problematiken. Hartman citerar bland annat memoarsvitens fjärde del, Givet (I968), där Colliander skriver: "Könet kräver, könet söker tillfredsställelse [...] Kärleken är fri från alla krav." ${ }^{29}$

I likhet med Berdjajev och Solovjov tillskriver Colliander kärleken ett unikt värde, där det sexuella begäret inte spelar någon avgörande roll. Utan att använda samma begrepp som Berdjajev i sin analys av

26. Ibid., s. 32. "In sacred, as well as in general history, sexual love is not a means to, or the instrument of, historical ends, it does not subserve the human species." Översättning till svenska: O.E.

27. Berdjajev, Om Dostojervkij, s. 85 .

28. Ibid., s. ro6.

29. Tito Colliander, Givet, Helsingfors: Holger Schildts förlag I968, s. 249; Olov Hartman, Ikon och roman, Stockholm: Skeab I980, s. I9. 
Dostojevskij, skiljer Colliander mellan passionens glöd och sedeslöshetens köld: mellan kärleken som är riktad mot personligheten och den blinda sexuella driften som är riktad mot en kropp och utesluter personligheten. Hartman citerar även en mening ur Collianders artikel "Perspektiv på sex och synd"i Hufoudstadsbladet 1965, där Colliander kritiserar preventivmedlen som ett redskap för att frigöra lusten och undvika dess följder: "Kärlekens öppna emottagande och givande utan förbehåll, dess villkorslösa frihet, har förvandlats till en trångt borgerlig egoism utan störande riskmoment." ${ }^{30}$

Den sanna erotiska kärleken utesluter egoism, självhävdelse och strävan att tillfredsställa sina begär; den sanna kärleken är omöjlig utan Guds närvaro i människans värld. Denna tanke är den etiska beröringspunkten mellan Colliander och de ryska filosoferna. I likhet med både Berdjajev och Solovjov, som poängterar kärlekens gränsöverskridande karaktär, skriver Colliander om kärlekens avgränsning som dess fiende; även sexualiteten, som en integrerad del av kärleken, måste bli infogad i sitt rätta andliga sammanhang.

\section{KärLEKENS FORMER I COLLIANDERS ROMANER}

Trots att Collianders omfattande författarskap består av texter i olika genrer såsom romaner, noveller, religiösa traktater och meditationstexter, kommer min analys att begränsa sig till tre skönlitterära verk: Korståget (1937), Grottan (1942) och Bliv till (1945). I dessa visar sig kärlekens problematik vara den tematiska katalysator som frilägger andra teman och motiv.

Collianders stora litterära genombrott, Korståget, inleds med en beskrivning av protagonisten Tomas ankomst till det revolutionära Petrograd efter att han en längre tid lidit av tyfus. I den smutsiga förfallna lägenheten hittar han i stället för sina föräldrar - som har flyttat till Finland under hans frånvaro - en oväntad hyresgäst, den trettioåriga kvinnan Dusia som är"klädd i en morgonrock, gylleneskiftande och prydd med svarta spetsar; det gula sidenet stack bjärt av mot

30. Tito Colliander,"Perspektiv på sex och synd", Hufvudstadsbladet 22/6 I965; Hartman, Ikon och roman, s. I8. 
dunklet och smutsen omkring henne." ${ }^{31}$ I romanen framställs Dusia utifrån Tomas perspektiv som ett ting som inte har några mänskliga egenskaper och som bara kan identifieras genom sin klädsel - den gylleneskiftande morgonrocken som blir ett återkommande motiv i romanens första del. Trots att Dusia har ett namn som i ryska språket betyder själ (dusia) kommer Tomas aldrig åt hennes själ och betraktar henne som en del av den obesjälade smutsiga tingvärlden; Dusia skildras som ett opersonligt föremål som smälter in med en divan som liknar"en praktfull blomstrande ö". ${ }^{32}$ Även intimitetens ögonblick beskrivs som ett ömsesidigt närmande av två fysiska själlösa kroppar:

Han såg upp, såg hennes leende mun och hennes ögon, och när han lutade ansiktet mot det mjuka sidenet vid hennes bröst, kände han värmen från en annan människokropp. Då gick en plötslig lättnad igenom honom och tyst började han gråta av svaghet. ${ }^{33}$

Det intima förhållande som Dusia och Tomas i sin respektive ångest kastar sig in i för dem inte närmare varandra utan fjärmar dem tvärtom från varandra. Efter samlaget upplever Tomas en onaturlig tomhet som "inte hade funnits där förr, aldrig, hur ofta han än hade varit ensam i rummet”. ${ }^{34}$ Genom att skildra förhållandet mellan Dusia och Tomas som en blandning av ömsesidig misstro och kroppsligt begär ger Colliander ett exempel på den blinda könsdriftens förödande kraft. Sexuella förhållanden som saknar den andliga grunden - eller det som Berdjajev i sin essä om Dostojevskij betecknar som Guds närvaro - är dömda till undergång. Det fysiska begärets gnista, som slumpmässigt har fört samman Dusia och Tomas, slocknar och förvandlas till hat och avsky. När de träffas efter en lång separation, då Tomas blir frigiven efter att ha suttit häktad i Rysslands största fängelse, Kresty i Petrograd, stirrar de in i varandras tomma ögon och

3I. Tito Colliander, Korståget, Helsingfors: Söderström C:o Förlagsaktiebolag I937, s. I3.

32. Ibid., s. 65 .

33. Ibid., s. 23 .

34. Ibid., s. 24 . 
vill bara slippa undan varandra: "Åter stod de tysta en stund, det var som ville de komma förbi varandra och försökte finna någon utväg." ${ }^{35}$ Deras desperata försök att tala med varandra på ett mänskligt sätt leder till en häftig uppgörelse och ett oåterkalleligt främlingskap. Tomas projicerar sitt grundlösa hat mot Dusia på den i hettan badande staden Petrograd, som påminner honom om ett klösande djur med hemska ögon. Känslan av att han undviker Dusia växer till en längtan att fly från staden och från ett land där han plågas av hunger, ångest och meningslöshet.

I Tomas ögon framstår Dusia som fulare och mer avskyvärd än hon är; under en blick som saknar kärlek och medlidande framträder kvinnans mest frånstötande drag. Däremot blir Dusias gestalt som förvandlad i förhållande till Boris, vars medlidande läker hennes innersta sår och öppnar själens vackraste sidor: "Boris kom varje dag och då blev allting ljust och allt fick fastare och klarare konturer. Allting började leva ett hemlighetsfullt liv, alla föremål fick ögon och andedräkt. Hon kände en stilla lycka." ${ }^{36}$ Samma Dusia som för sansade och innerliga samtal med Boris och fördjupar sig i tankar om Jesus och kors, nunnornas svarta dräkter och kalla stengolv, kan samtidigt förödmjuka sig genom att kasta sig in i slagsmål med Tomas, yla hysteriskt, riva sitt hår och klösa sig i ansiktet.

I romanens andra del,"Nea", slits Tomas mellan sin evigt förlåtande hustru och den vilda och fria Nea som inte har några spärrar i sin omåttliga spaning efter nöjen. Nea, som skrattar, jollrar och obegränsat dricker brännvin, skänker Tomas en tillfällig befrielse från skuldkänslan och den förtärande ångesten som genomsyrar hans tillvaro:

Inför henne kunde han göra det raljerande som ett skämt. [...] Han vållade henne inte en smärta, som blev outhärdlig när den kastades tillbaka med alla ekon från en annan själ, en själ som han älskade och som älskade honom. ${ }^{37}$

35. Ibid., s. I25.

36. Ibid., s. Io7.

37. Ibid., s. 343 . 
Tomas kärlek till Nea har sitt ursprung i den andliga samhörigheten och berör inte bara kroppen utan framför allt själen. När han ser en skymt av Neas vita kropp känner han ingen attraktion, "bara en underlig lycka, som hade hon sagt någonting vackert till honom, någonting som berörde henne intimt och som hon endast visade för honom". ${ }^{38}$ Denna blygsamma intimitet visar sig vara ett frö till en flammande passion som Tomas inte förmår motstå:

Det var som en hemlig kraft sugit alla hans tankar till Nea, han såg henne överallt [...] Telefonen blev ett levande väsen som ropade med Neas röst - men nästan alltid visste han redan en timme tidigare om han skulle följa den eller inte. ${ }^{39}$

Kärlekens dualism, som Berdjajev skriver om, avspeglas även i Collianders berättelse. Nea förkroppsligar sensualitetens kraft, som berusar Tomas med en känsla av absolut frihet och normlöshet. Tomas hustru Dusia däremot representerar kärlekens motsatta pol - det tysta medlidandet som har en exalterad och uppoffrande karaktär. Hustrun är en bärare av den lidelsefulla kärleken, i vilken medlidande och självuppoffring dominerar över alla andra känslor. I Dostojevskijs anda kan denna kvinnliga gestalt tolkas som ett förkroppsligande av medlidande och ödmjukhet. Hennes "underligt smärtsamma leende" och hennes tysta väntan plågar Tomas på samma sätt som Neas oförutsägbara impulser. I Dusias medlidande och Neas sensuella glöd ligger samma kraft som dränerar Tomas själ i stället för att fylla den med glädje.

Berdjajevs uppfattning om kärlekens problematik i Dostojevskijs författarskap är relevant för Collianders skildring av den kärlek som leder till en inre söndring i själen. Varken medlidandet, som Tomas riktar mot sin hustru, eller vällusten som han upplever i förhållande till Nea, skänker protagonisten tillfredsställelse eller stillar hans inre oro:

Varje förnimmelse, utom förruttnelsens, upplösningens, den vämjeligt formlösa slöhetens, var bortrunnen, och han själv rann allt längre ut i en tjockflytande ström mot en avgrund. Och i avgrunden var bara

38. Ibid., s. 288.

39. Ibid., s. 349 . 
gapande hemskhet. Illamåendet, den pulserande värken över ögonen - allt drunknade i denna förfärliga avgrund. ${ }^{40}$

Ordet"avgrund" upprepas tre gånger i beskrivningen av protagonistens fysiska och själsliga tillstånd. Kärleken hos Colliander blir, om man uttrycker det med Berdjajevs ord,"ett glödande järn" som inte skänker någon lycka eller tröst. ${ }^{41}$ I likhet med Dostojevskij visar Colliander vägen ut ur den ångestfulla cirkel som hans protagonist hamnat i. Det som kännetecknar Dostojevskijs berättelser är ett ljus som alltid skymtar i människosjälens mörka labyrint. Hos Dostojevskij har varje människa en chans till frälsning och återuppståndelse. Det väsentliga i hans antropologi är att den sanna kärleken, den kärlek som för människan till en annan dimension och förädlar hennes sinne, är den kristna kärleken. Denna tanke framhävs av Berdjajev som skriver att sensualiteten och medlidandet som kärlekens två poler "bör [...] upplysas genom närvaron av Gud med den älskade". ${ }^{42}$ Kärleken är inte destruktiv, förutsatt att man accepterar och älskar den gudomliga formen i sin nästa:

Att älska människan, om Gud inte finns, skulle betyda, att man gudomliggör människan och dyrkar henne som Gud. Detta leder till en farlig vantro på Människoguden, som måste uppsluka och förslava individen. ${ }^{43}$

Genom liderlighetens dödliga kyla, genom medlidandet och vällustens avgrunder, leder Colliander sin protagonist till ljuset som han finner i korstågets särskilda skönhet. Ikonerna, bönerna och de heliga sångerna blir för honom den andliga kraftens källor. Korståget innebär en rörelse framåt; tillsammans med denna fysiska rörelse utvecklas människans andliga kraft, som för Tomas betyder att han lämnar bakom sig ett

40. Ibid., s. 323 .

4I. Berdjajev, Om Dostojevskij, s. 95."Man förstår lätt, hur kärleken, som låter människan genomgå en sådan process, hos Dostojevskij nästan alltid är demonisk. Den skapar besatthet och höjer den omgivande luftens temperatur, tills du blir som glödande järn."

42. Ibid., s. II9.

43. Ibid., s. I23. 
gapande tomrum, en förtorkad mark. Genom att delta i korståget, sjunga heliga sånger och dela bröd och vatten med andra människor övervinner Tomas sin inre kluvenhet och träder in på en annan mark där han finner ljuset och det andliga fästet i sin egen själ. Han själv blir källan till den kärlek som han längtat efter:

Det darrade till i hans inre, en känsla av värme och kärlek. Jag måste ju gå med - hur kunde jag tänka mig något annat! Och som den avlägsna början till ett mäktigt brus, än så länge endast anat, strömmade den underliga lyckokänslan igen emot honom. ${ }^{44}$

Kärleken som uppstår i Tomas själ genom Guds välsignelse är förankrad i den kristna tron och skänker därför efterlängtad frihet och styrka. Samma kluvenhet karakteriserar en annan av Collianders protagonister, Sergej Virigin i Bliv till. Sergej är en rysk entreprenör som lever ett utsvävande och lyxigt liv i Paris. Detta liv tillfredsställer honom inte, utan ger upphov till en känsla av allt djupare inre söndring. Han lider av brist på andlighet och föraktar sig själv för kroppens svaghet som drar in honom $\mathrm{i}$ en andlig avgrund där han möter tomhet och ångest: "Bara kött, bara kött, bara kött! Efter en sådan natt känner man sig alldeles urlakad. Och om igen, om igen." ${ }^{45}$ Sergej plågas av en oemotståndlig sexuell dragning till en svart dansös, Dolores, som berövar honom hans inre frihet; det fysiska tar makten över honom och gör honom till kvinnans of rivilliga slav: "Fick en otäck känsla av att hon är jag. En del av mig - kanske. Fastvuxen. Vid penis? Den växer in i henne och jag ruttnar bort." ${ }^{46}$ Den fysiska sammansmältningen med den svarta dansösen orsakar Sergej en personlighetsförlust som han endast kan bekämpa genom ett vända sig till sina andliga rötter som förkroppsligas av den ryska ortodoxa kyrkan. Efter en bilolycka i vilken Dolores omkommer lämnar Sergej societetslivet bakom sig och väljer att vigas till munk.

44. Colliander, Korståget, s. 399.

45. Tito Colliander, Bliv till, Stockholm: Fahlcrantz \& Gumaelius I945, s. I79.

46. Ibid., s. I95. I Collianders berättelse upplever Sergej Virigin den svarta kvinnan Dolores som ett exotiskt och tilldragande föremål som kommer från en annan kultur och aldrig kan komma honom nära på ett andligt plan. Beskrivningen är rasifierande på ett tidstypiskt sätt. 
Kärlekens tragik tar sig uttryck i skildringen av romanens andra protagonist som också är en berättare - den unge fattige målaren som blir förälskad i den begåvade pianisten Majou. I motsats till Majou som ägnar sitt liv åt musik och konst hamnar protagonisten i kärlekens fångenskap där han förlorar sin inre frihet och därmed sin förmåga att skapa:

Men skulle jag inte förlamas så fort hon var borta? Min tanke skulle grumlas, mina händer bli svaga - skulle inte allt bli dött och likgiltigt för mig, tungt som portföljen med de osålda teckningarna under min arm? Skulle jag alls kunna arbeta? ${ }^{47}$

Skildringen av den unge konstnärens tragiska kärlek till Majou står i samklang med Berdjajevs syn på svartsjukan som ett "tyranni över människan". ${ }^{48}$ I"Reflexioner om Eros" framhäver Berdjajev en annan viktig tanke som förekommer i Bliv till, nämligen tanken om en tragisk konflikt mellan kärleken och skapandets frihet. ${ }^{49}$ Som filosof är Berdjajev besatt av frihetens tanke. Friheten, bland annat skapandets frihet, värderar han högre än den erotiska kärleken.

I skapandet, som kräver hela människan, måste hon vara fri från den inre frihetens värsta fiender: svartsjukan och vällustens glöd. I Collianders roman representeras denna tanke av en talande kontrast mellan två typer av konstnärer. Den första är berättaren, den unge målaren som förlorar sin förmåga att skapa genom den erotiska kärleken som visar sig vara en enda plåga för honom: "Ingenting föddes inom mig, och om det föddes, om jag tyckte det fanns någonting som sökte form, var min hand vanmäktig." ${ }^{50}$ Den andra typen av konstnärer personifieras av berättarens vän, skulptören Rank, vars motto blir den konstnärliga frihetens absoluta värde: "Man ska inte bli kär. Då går det åt helvete med en." ${ }^{51}$ Till de fria konstnärernas läger hör Majou, berättarens kärlek, som inte tar sina erotiska förhållanden med män på allvar utan fullkomligt koncentrerar sig på sin roll som

47. Ibid., s. I70.

48. Berdjajev, Om Dostojerskij, s. 88.

49. Berdjajev,"Reflexioner om Eros", s. 84 .

50. Colliander, Bliv till, s. 52 .

5. Ibid., s. I24. 
pianist - utan andra uppgifter än att utveckla sitt spelande och på så sätt växa som musiker.

Romanen avslutas med ett brev av Majou till den förälskade berättaren, där hon beskriver sitt andliga uppvaknande genom pianospelet: ”Det känns lustigt. Det känns gåtfullt. Det är som en väg framför mig, jag vet ingenting om den, bara att jag måste gå. Har jag blivit till först nu?" 52 I motsats till Rank, som förnekar själva möjligheten att älska till förmån för det fria skapandet, utesluter Majou inte den erotiska kärleken från sitt liv. Hennes kärlek är dock alldeles för ytlig och därför smärtsam för det älskade föremålet. Konsten visar sig vara det enda som verkligen har någon betydelse för henne. I viss mån är Majou musikens tjänarinna, men till skillnad från berättaren som är kärlekens slav finner hon genom sin kärlek till musiken vägen till de andliga dimensionerna och det fyller henne med en känsla av frihet och glädje.

Den erotiska kärlekens tragik kan sålunda övervinnas genom den andliga pånyttfödelsen inom den ortodoxa kyrkan, som i Sergej Virigins fall, eller genom det konstnärliga skapandet som kräver uppoffringar, som i Majous fall. Den inre friheten, som är grunden till den sanna kärleken, kan således uppnås både genom den religiösa tron och genom det konstnärliga skapandet.

Kärlekens tragik och människans väg till den sanna kärleken står i fokus också i Collianders roman Grottan (I942), en kärleksberättelse i vilken den unga servitrisen Märta slits mellan två män som älskar henne: den äkta maken, den motsägelsefulle musikern Erik, och vännen och beundraren, den öppenhjärtige seglaren Rolf. Den manliga protagonisten Erik karakteriseras som "en av dessa säregna gränsmänniskor utan bestämd nationalitet och inre hemortsrätt, lika mycket balttysk som svensk eller finsk, delvis uppväxt i Finland, utexaminerad från musikakademin i Petersburg". ${ }^{53}$ Erik saknar rötter och andliga pelare, vilket får honom att balansera på randen till avgrunden utan den kristna tron och förmågan att älska osjälviskt.

52. Ibid., s. 276 .

53. Tito Colliander, Grottan, Helsingfors: Söderström \& C:o Förlagsaktiebolag 1942, s. 240. 
Berättelsen börjar med Eriks återkomst till hustrun Märta efter ett års frånvaro. Han har tidigare lämnat Märta efter att ha fått veta att hon har ett utomäktenskapligt barn, dottern Birgitta, som omhändertagits av en fostermor. Märtas fasta beslut att adoptera sitt eget barn efter fostermoderns död utlöser ett raseriutbrott hos Erik och leder till att han demonstrativt bryter med henne. Erik kan dock inte motstå den glödande vällust som Märta framkallar hos honom och den fysiska dragningen får honom att söka sig tillbaka till hustrun. Vällusten smittar av sig även på Märta, som lämnar dottern och flyttar till Eriks hyresrum för att tillbringa några kärleksnätter med honom. Det sexuella ruset som de går in i efter den långa separationen får dock ett abrupt slut och övergår i ett ännu större missförstånd och ett ömsesidigt främlingskap. Känslan av tomhet och meningslöshet överväldigar Erik; i stället för att fyllas med glädje och tacksamhet störtar han ner i ångestens avgrund där världen framstår som kvalfull och avskyvärd:"Men på morgonen låg han med tungt huvud och trötta lemmar under det tillskrynklade lakanet. Luften var kvav, solljuset i fönstret var olidligt." ${ }^{54}$ Även Märta grips av förtvivlan och inser det meningslösa och falska i deras förhållande, som uteslutande baseras på den fysiska attraktionen:"Hon kände tomhet gapa där bakom. Var det verkligen så? Var det tomhet? Så hade hon aldrig känt förut." 55 Utan ett spår av saknad eller sorg lämnar Märta Eriks hyresrum och återförenas med med sin dotter. Birgittas tillit visar sig vara mer betydelsefull än passionens glöd, som i ett enda svep förvandlas till en isande kyla.

Eriks kluvenhet står i motsättning till Märtas inre helhet. Märta är en bärare av den sanna kärleken, som kastar ljus över Eriks mörker. Mot slutet av berättelsen blir kontrasten mellan det mörka och det ljusa skarpare. Eriks mörker och Märtas ljus möts i romanens sista scen, där Erik, som är nära att begå självmord, ser Märta stå framför sig: "Helt solbelyst stod hon där på den breda gångbanan framför ingången till restaurangen, så ljus, så rak och öppen som hon verkligen var." ${ }^{56}$ Vid åsynen av Erik förstår Märta "hur hemskt och djupt det

54. Ibid., s. Io9.

55. Ibid., s. I25.

56. Ibid., s. 320 . 
mörkret var, ur vilket han nu skulle stiga ut, likt en kvävande grotta var det, och det gav henne en stöt som en kroppslig smärta”. ${ }^{57}$

I Märtas mångfaldiga gestalt förkroppsligas flera idéer som är karakteristiska för både Dostojevskij och Solovjov. Märta har vissa likheter med Dostojevskijs lidelsefulla kvinnliga karaktärer. När hon står inför valet mellan den egoistiska, förlorade Erik, och den kärleksfulla och goda Rolf, avvisar hon Rolf till förmån för Erik, vilket för henne innebär osäkerhet, ångest och rotlöshet. Erik som saknar inre kraft är hatad av Märtas dotter Birgitta, som däremot avgudar Rolf som om han vore hennes älskade far. Trots detta väljer Märta Erik och utsätter därmed sig själv och sitt barn för lidande. I sitt medvetna val är Märta vägledd av medlidande - en känsla som har lidande i sin grund. I Dostojevskijs anda går Märta i strid mot förnuftet och väljer bort trygghet, glädje och sinnesfrid. Märtas val är en räddningsakt där hon tar på sig en martyrroll. Hon bestämmer sig medvetet för att dela Eriks lott och ge honom hopp, även om det sker på bekostnad av hennes egen lycka. Samtidigt visar sig Märtas beslut inte vara spontant; det beskrivs som en gudomlig uppenbarelse då hon står på verandan och iakttar naturens avspeglingar i en stor glaskula som ligger på gräsmattan mellan trappan och sandstranden:

Plötsligt fångade silverkulan där ute ljus. Det var som hade den dragit det till sig någonstans ifrån, och samlade det, allt mera levande. [...] Renbadad öppnade sig landskapsbilden med stranden, landtungorna, havet, och åter låg horisontlinjen blå och skarp. [...] Hon kastade sin regnkappa över axlarna och gick köksvägen ut. ${ }^{58}$

Genom det tysta iakttagandet av glaskulans ljusspel upplever Märta samhörighet med världens gudomliga väsen i Solovjovs bemärkelse; det är som om den gudomliga skapelsens själ tilltalar Märta genom glaskulan och hjälper henne att fatta livets viktigaste beslut. I Märtas karaktär förkroppsligas den sanna kristna kärlekens idé. Denna kärlek utesluter egoism, svartsjuka och behov att äga den andra och medför en förmåga att möta den andra människans mörker och se Guds avbild

57. Ibid., s. 328 .

58. Ibid., s. 282. 
i varje människa. Märtas kärlek är gränsöverskridande i Dostojevskijs och Solovjovs bemärkelse; den överskrider hennes egen egoism och är medlidsam och förlåtande i sin inställning till den andra människan, som har ett absolut värde.

\section{Slut ORD:}

\section{COLLIANDER I DEN RYSKA KONTEXTEN}

Man finner spår av Dostojevskijs och Solovjovs syn på kärlekens problematik i Collianders filosofiska reflexioner och hans skönlitterära verk. Collianders dubbelroll som betraktaren och bedjaren - som Hartman skriver om - ger sig till känna i hans texter som karakteriseras av en viss motsägelse. Som betraktare eller iakttagare är Colliander konsekvent och tydlig. I sina artiklar och religiösa traktater, till exempel $\mathrm{Nu}$ och alltid, framhäver han tanken om andligheten som den nödvändiga grunden för kärleken, inklusive den kristna kärleken till Gud som den enda källan till människans inre styrka.I detta avseende har Colliander etiska beröringspunkter med Solovjov, som betraktar varje människa som Guds avbild och en integrerad del av universums levande själ.

Collianders synpunkter på kärlekens problematik är även influerade av Dostojevskij som ställer kärleken till Kristus högst av allt. Med utgångspunkt i Solovjovs reflexioner om kärlek och Berdjajevs tolkning av Dostojevskij kan man formulera de ryska filosofernas grundtanke om människans kärlek och sexualitet; kärlek är framför allt att övervinna sin egen egoism till förmån för den andra människan, som i kärlekens ögon framstår som Guds avbild. Sexualiteten måste fångas i dess rätta andliga sammanhang - $\mathrm{i}$ annat fall blir människan könets slav. Dessa postulat kommer till uttryck i Collianders roman Korstaget, i vilken han visar protagonisten Tomas andliga väg upp från avgrunden, där egoism, svartsjuka, vällust och leda råder, till ljuset som förkroppsligas av korståget och kyrkan. Deltagandet i korståget och mötet med kyrkan blir för Tomas de avgörande stegen på vägen till en andlig pånyttfödelse, som också är en grundsten till upplevelsen av den sanna kärleken i begreppets kristna bemärkelse.

I likhet med Dostojevskij visar Colliander den sanna kärlekens fria väsen; den är fri från samhällets konventioner som medför olika 
former av plikt. Denna tanke avspeglas tydligt i memoarsvitens sjunde del, Måltid (1973), där Colliander framhäver det oupplösliga sambandet mellan kärleken och friheten:

Ett liv som leds av enbart pliktkänsla är hårdkammat. [...] Ett liv som leds av kärlek är fritt från sådana krav. Det lever och får all sin näring och alla sina behov tillfredsställda av kärleken. ${ }^{59}$

Den erotiska kärleken är också fri från sexuellt begär. Den utesluter inte en kroppslig närhet, men fysiologin är inte en avgörande faktor för kärleksrelationer. Grunden till den sanna erotiska kärleken är andlighet. Varje människa måste ses som Guds avbild, och kärlekens uppgift är att få fram det gudomliga i den andra människan, så att man kan se denna avbild i den man älskar. Denna syn på den erotiska kärleken som fri från rent sexuellt begär förekommer i Collianders korrespondens med hustrun Ina, där han beskriver sitt tvivel beträffande det sexuella livets moraliska aspekt:

Men en tyngd finns kvar: det ofullständiga och förkrympta, kanske syndiga i vår samvaro - jag menar undvikandet av att få barn. Jag förstår inte hur jag ska kunna fortsätta med det sedan, när vi är vigda. Du har kanske svårt att fatta det, du är inte den utförande, men jag känner det ofta som ett äckel, ett smutsigt mord, eller som om jag plötsligt i den stunden eller strax efteråt skulle förflyttas till en bordell. ${ }^{60}$

Med detta vill Colliander säga att äktenskapet framför allt är en andlig förening mellan två människor. Det sexuella förhållandet inom äktenskapet borde inte eftersträva fysisk njutning utan syfta till att skaffa barn. På detta sätt kan varje människa delta i Guds ursprungliga idé att förena en man och en kvinna för att inte låta människosläktet dö ut.

Teoretikern och teologen Colliander ger ändå företräde åt konstnären i romanerna Bliv till och Grottan, i vilka kärlekens problematik omtolkas. Bedjaren blir till betraktare när han skildrar kärlekens tragik

59. Tito Colliander, Måltid, Skellefteå: Artos 1973, s. 67.

6o. Tito Colliander till Ina Colliander, 20/8 1937, Tito och Ina Collianders arkiv, 866, Svenska litteratursällskapets arkiv (SLSA), Helsingfors. 
i dess motsägelsefulla former. I Dostojevskijs anda pekar Colliander på de manliga protagonisternas inre kluvenhet, som leder till en oförmåga att älska och välja mellan det goda och det onda. Collianders karaktärer besitter inte samma intensitet som Dostojevskijs. Trots deras inre söndring blir varken Sergej Virigin i Bliv till eller Erik i Grottan den absoluta ondskans eller den gränslösa liderlighetens bärare - till skillnad från Dostojevskijs Svidrigajlov, Stavrogin eller Pavel och Fjodor Karamazov. Sergej Virigins andliga lidande kan inte jämföras med Ivan Karamazovs inre mörker som driver honom till vansinne; Eriks demoniska besatthet av Märta uppnår inte samma nivå som Rogozjins förödande passion för Nastasia Filippovna. Dostojevskijs alla protagonister är besjälade idéer; Stavrogin, Rogozjin, furst Mysjkin samt fadern och bröderna Karamazov förkroppsligar olika laster och dygder såsom liderlighet, vällust, gudlöshet, medlidande och godhet.

Collianders karaktärer är däremot psykologiska människotyper som lider av rotlöshet, svartsjuka, inre of rihet, beroende av sina begär och ambitioner samt brist på andlighet. I Bliv till och Grottan kan den erotiska kärleken aldrig vara fullbordad och lycklig i ordets borgerliga bemärkelse. I Bliv till kan kärlekens tragik övervinnas genom det fullkomliga förnekandet av den erotiska kärleken till förmån för kärleken till Kristus i mötet med den ortodoxa kyrkan, som i Sergej Virigins fall, eller i det konstnärliga skapandet som kräver uppoffringar, som i skulptören Ranks och pianisten Majous fall. I Grottan står den manliga protagonistens kluvenhet i motsats till kvinnans inre helhet och andliga styrka. Märta i Grottan förkroppsligar medlidandets läkande kraft som skänker mannen hopp om pånyttfödelse - det som är kärlekens mening. Kärleken har hos Colliander ingenting med lycka att göra utan innebär ett hårt själsligt arbete som kräver uppoffringar. Den erotiska kärleken är en prövning som ofta leder människan in $i$ en andlig återvändsgränd, men den kan också vara andlighetens vägledande kraft som för samma människa till ett möte med Guds ansikte och en försoning med världen - Guds skapelse.

Skillnaden mellan Collianders och Dostojevskijs respektive framställning av kärlekens problematik gäller också de kvinnliga karaktärerna, som har olika funktioner i de två författarskapen. Berdjajev framhäver att kvinnan hos Dostojevskij aldrig uppträder som en självständig personlighet utan kan uppfattas som "en del av ett 
manligt öde och som en etapp på hans väg”. ${ }^{61}$ Berdjajevs analys av kvinnogestalter i Dostojevskijs författarskap bygger på Berdjajevs filosofiska syn på kvinnan som en katalysator för mannens tillstånd och tillvaroformer. Berdjajevs syn på kvinnan är inte kränkande eller nedvärderande utan snarare manscentrerad; den varken förminskar eller utesluter kvinnans betydelse, utan tillskriver henne en roll som antingen inspirationskälla för det manliga skapandet eller ett vapen för att förgöra mannen andligt eller till och med fysiskt. Berdjajevs kvinnosyn leder sitt ursprung från hans estetiska och filosofiska föreställningar om frihetens absoluta värde och skönhetens ödesdigra makt över människans tillvaro. Mannen i Berdjajevs filosofi är en bärare av den absoluta inre frihetens idé, medan kvinnan förkroppsligar skönhetens idé. Människotillvarons tragiska dialektik ligger i denna olösliga konflikt mellan mannens ursprungliga strävan efter friheten och hans fascination inför kvinnan som är skönheten förkroppsligad.

Till skillnad från Dostojevskijs och Berdjajevs människosyn, där mannen står i fokus, spelar Collianders kvinnliga romangestalter på samma plan som de manliga. Märta i Grottan, Majou i Bliv till och Nea i Korståget är inte bara en del av de manliga romangestalternas öden och orsaken till deras uppvaknande eller förfall, utan har själva en skapande kraft som kan överglänsa mannens - i till exempel Bliv till visar sig Majou vara den passionerade äkta konstnären. Hos Dostojevskij förkroppsligar de kvinnliga romangestalterna vissa idéer eller krafter, såsom ondska, lidande, godhet eller ödmjukhet. Dessa krafter visar sig vara katalysatorn för de manliga romangestalternas öden. Colliander skildrar i de flesta av sina romaner kvinnor som psykologiska typer och självständiga karaktärer som agerar på samma villkor som män; de fattar självständiga beslut och väljer sina egna vägar som ofta är avgörande för romanens handling.

6I. Berdjajev, Om Dostojerskij, s. 9r. 